\title{
Sciendo
}

Rocznik Pedagogiczny 42/2019

PL ISSN 0137-9585

DOI $10.2478 / \mathrm{rp}-2019-0010$

VERED AZULAY

Kannot Youth Village, Beer Tuvia

\section{PROFESSIONAL BURNOUT AMONG TEACHERS \\ IN THE REGULAR SCHOOLS AND YOUTH VILLAGES IN ISRAEL}

\section{INTRODUCTION}

The research of Gavish and Friedman ${ }^{1}$, who examine the burnout of teachers in their first year of work, shows that teachers coming from a process of training are already mentally burned out even before they began to work. Some maintain that the training programs which emphasize 'what to teach' and less the meaning of 'being a teacher' may place difficulties on teachers at the start of their path ${ }^{2}$.

The research study of Friedman and Lotan ${ }^{3}$ reports several factors that influence the teacher's mental burnout: reciprocal relations of the teachers with their students and the interpersonal relations among the students themselves. The teachers' pedagogical efforts in their students' scholastic-educational achievements influence the process of their burnout, as do the absence of cooperation and the feeling of alienation in the school. Fisherman ${ }^{4}$ presented the approach of Greenfeld to causes of teacher burnout: workload, role conflicts, teachers' personality, leadership personality, discipline problems, interpersonal relations with the school staff, the decision-making process, and the decline of teacher status ${ }^{5}$.

1 B. Gavish, Y. Friedman, The Teacher as an Organizational Person: The Contribution of the Perceived Work Environment of the Beginning Teacher to the Prediction of Burnout in the Beginning and at the End of the First Year of Work, "Studies in the Administration and Organization of Education" 2007, 29, 55-81 (Hebrew).

2 D. Pritzker, D. Chen, Factors of Burnout in Teaching among Teachers in Their First Years of Work, "Study and Research in the Training of Teachers" 2010, 12 (Hebrew).

3 Y. Friedman, A. Lotan, Mental Burnout of the Teacher in Israel in Elementary Education, Research Report, Henrietta Szold Institute, 1985 (Hebrew).

4 S. Fisherman, Professional Identity and Burnout among Teaching Workers, Shanan, Haifa 2016 (Hebrew).

5 A. Greenfeld, The Technological Pedagogical Center, The Educational Networks of the Economic Union of Workers in Israel, "The Technological Pedagogical Center, the Amal Network, the Pedagogy Department” 1990 (Hebrew). 
Dvir showed how personal and interpersonal factors, such as sense of self-efficacy and social support, mediate between the pressuring work environment and burnout. In addition, the support of the principals and supervisors is important in the teacher's work ${ }^{6}$.

A research study conducted by Van Droogenbroeck, Spruyt, and Vanroelen ${ }^{7}$ evaluated the influence of four types of interpersonal relationships: with the students, with the peers, with the supervisors/instructors, and with the parents. Teachers were found to be motivated by the desire to learn and help children ${ }^{8}$. The interaction between the teachers and their environment and work partners is one of the most common sources of the experience of stress and burnout among teachers. Burnout is caused by the combination of the work requirements that include psychological, organizational, and physical aspects of the work ${ }^{9}$.

The research of Friedman and Lotan found that the characteristics of the school structure caused increased burnout of teachers: large schools, which have, clean and orderly structure, and an atmosphere of discipline and order. In the management field there is a clear and defined hierarchy, there is a deputy, and there are many role-holders. The management style is authoritarian, and the management strongly pushes for high achievements. There is a lack of personal support. In contrast, in schools without burnout, the structure is small, intimate, and warm, the structure is not $100 \%$ clean, the management environment is not defined, there is a management team, and there are a large number of meetings with the teachers ${ }^{10}$.

The term 'boarding school' is a term for institutions in which people live most of the days of the year under one main authority. The trend of the boarding school is to influence in a certain direction or to cause a change in the students ${ }^{11}$. The boarding school is perceived as a powerful environment, since it pushes the

${ }^{6}$ B. Gavish, I.A. Friedman, Novice Teachers' Experience of Teaching: A Dynamic Aspect of Burnout, "Social Psychology of Education" 2010, 13 (2), 141-167; E.M. Skaalvik, S. Skaalvik, Does School's Context Matters? Relations with Teacher Burnout and Job Satisfaction, "Teaching and Teacher Education" 2009, 25 (3), 518-524.

${ }^{7}$ F. Van Droogenbroeck, B. Spruyt, C. Vanroelen, Burnout among Senior Teachers: Investigating the Role of Workload and Personal Relationships at Work, "Teaching and Teacher Education" 2014, 43, 99-109.

${ }^{8}$ K. Struyven et al., Why Do They Want to Teach? The Multiple Reasons of Different Groups of Students for Undertaking Teacher Education, "European Journal of Psychology" 2012, 1-16.

9 M.L. Chang, An Appraisal Perspective of Teacher Burnout: Examining the Emotional Work of Teachers. "Educational Psychology Review" 2009, 21, 193-218.

${ }_{10}$ Y. Friedman, A. Lotan, Stress and Burnout in Teaching - Causes and Ways of Prevention, Henrietta Szold Institute, Jerusalem 1993 (Hebrew).

11 D. Dagan, The Relationship of Coping and Locus of Control to the Adjustment of Immigrant Students from Ethiopia to the Boarding High School, Master Thesis, Bar Ilan University, School of Social Work, Ramat Gan 1997 (Hebrew). 
students to internalize clear and understood norms and to adjust to them through their continuous exposure to their influences ${ }^{12}$.

The boarding school is an inclusive name for the agricultural schools, institutions for adolescents, youth villages, and other arrangements outside of the home, which engage in education or care. The common denominator of these frameworks is a regular activity of multi-professional staff members, which help and direct the students. The boarding school method of education is more widespread in Israel than in other countries in the world. Moreover, Israel is one of the countries where the percentage of adolescents who are educated in the boarding schools is the highest ${ }^{13}$.

The population of residents in the youth villages and educational boarding schools includes youths going through identity crises ${ }^{14}$. In the countries of the Western world, the boarding school is perceived as 'rehabilitating' for the youth who have attempted and failed in the regular system. The boarding school is perceived as a negative alternative, and therefore it is perceived less and less as a solution for youth ${ }^{15}$.

Today, in light of the review of the literature and the different research studies undertaken on the topic of the boarding schools, the main influence of the boarding school on the student is expressed in two primary areas. The first area is the disconnection of the student from society and the community. The educational boarding school is a place where the adolescents spend most of their time for a number of years, until they are adults and enlist in the Israel military ${ }^{16}$.

The second area is the educational influence of the boarding school institution. This influence is derived as an outcome of the homeroom teacher's activity, which influences all areas of the adolescent student's life ${ }^{17}$.

${ }^{12}$ Y. Keshti, A. Manor, Boarding Schools in Israel: Continuity and Change, Tel Aviv University, Tel Aviv 1988 (Hebrew); Y. Wosner, M. Golan, B. Arad-Davidson, Quality of Life in the Boarding Schools for Children and Youths in Israel: Summative Research Report, Ministry of Labor and Welfare, Jerusalem 1993 (Hebrew).

${ }^{13}$ E. Grupper, To Be an Instructor in the Boarding School: An Ethnographic Investigation of the Process of the Professional Socialization of New Workers to Their Role, Doctoral Dissertation, School of Education, Haifa University 1992 (Hebrew).

${ }^{14}$ Z. Levy, The Lifestyle in the Boarding School and the Shaping of the Identity of Adolescents, [in:] Communities of Youths, eds. Y. Keshti, S. Shlasky, M. Arieli, Ramot, Tel Aviv 2000 (Hebrew), 21-33.

15 E. Grupper, The Boarding Schools in Israel: An Original Creation of the Educational System, [in:] Boarding School Education in Israel, ed. S. Shamay, The Educational Center, The Administration for Community Education and Youth Immigration, Tel Aviv 2004 (Hebrew).

${ }^{16}$ G. Ariel, A. Milstein, What We Dreamed About: The Legend of the Hadassim, Hisardut 2006 (Hebrew).

${ }^{17}$ D. HaCohen, Children of Time: Youth Aliyah, 1933-1948, Yad Vashem, The International Ins, Jerusalem 2001. 
From the establishment of the State of Israel until today, the network of boarding schools in Israel was extended in a way that is exceptional relative to other countries in the world. The youth villages and educational boarding schools are a unique model of residential education in Israel.

\section{THE YOUTH VILLAGE - AUTHOR'S RESEARCH}

The uniqueness of the youth village is the integration of the boarding school and the school from an educational view with a character that contributes to Israeli society and constant treatment work with the students ${ }^{18}$. In Israel there are about 60 youth villages that are distinct from one another according to the population of the adolescents, the physical size of the village, and the resources at its disposal. The youth village is the leading prototype of the model of the educational boarding school in Israel. This is an original creation of the Israeli educational system, which does not exist in other places in the world. The inspiration for its implementation is taken from the model of the kibbutz and from the educational ideas of that movement. The main ideas at the basis of this boarding school model are:

1. The creation of a social structure that can include and educate the youths who come from a different cultural background, when their common denominator is the need for a residential, outside of their home.

2. The creation of balance between education and the realization of social objectives abilities and personal capabilities that fulfill the individual's self-realization.

3. The creation of an educating community, which cares for and presents the students with normative educational challenges for those their age, which enable the youths to act and be partners in the management of their life routine ${ }^{19}$.

\section{Research Participants}

The research participants consist of 73 teachers who work with youths at-risk in youth villages in Israel and 70 teachers who work in regular schools, for the total of 143 teachers.

${ }^{18}$ E. Grupper, Boarding Schools in Israel: Social Educational Frameworks and Their Dimensions, [in:] S. Romy, M. Shmeyda (eds.), Informal Education in a Changing Reality, Magnes Press, Jerusalem 2007 (Hebrew).

19 E. Grupper, The Boarding Schools in Israel: An Original Creation of the Educational System, [in:] Boarding School Education in Israel, ed. S. Shamay, The Educational Center, The Administration for Community Education and Youth Immigration, Tel Aviv 2004 (Hebrew). 


\section{Research Instruments}

A 5 segment self-reporting questionnaire was distributed:

- Factors of support: 7 items, Likert 1-5. Value was the mean, where a high value indicates considerable presence of support factors in the workplace. (Cronbach's $\alpha=0.69$ ).

- Factors of leaving the teaching profession: 28 items, Likert 1-5. (Cronbach's $\alpha=0.93$ ).

- Teacher student relations: 7 statements, Likert 1-4. A high value indicates the close relations of the teachers with their students. (Cronbach's $\alpha=0.70$ )

- Efficacy in teaching with students with different needs: 16 items, Likert 1-4. high value indicates a high efficacy. (Cronbach's $\alpha=0.80$ ).

- Burnout: 14 items, Likert 1-4.high value indicates a high level of burnout. (Cronbach's $\alpha=0.90$ ).

\section{Research Results}

Table 1 presents the relationships between the main research indices among the teachers in the youth villages. It was found that the presence of support factors is positively related to the departure from the teaching profession $(r=.324, p=.005)$, so that as the presence of the support factors is more significant, the factors of the departure from the profession are more significant. In addition, a negative relationship was found between the index of the presence of support factors and the index of professional burnout $(\mathrm{r}=-.301, \mathrm{p}=.034)$, so that the participants with many significant support factors in the workplace tended to lower levels of professional burnout. It was further found that high levels of teacher-student relations are positively related with higher levels of efficacy in teaching $(r=.371, \mathrm{p}=0.001)$.

Table 1. Main Research Indices - Teachers from Youth Villages

\begin{tabular}{|l|c|c|c|c|}
\hline & $\mathbf{1}$ & $\mathbf{2}$ & $\mathbf{3}$ & $\mathbf{4}$ \\
\hline 1. Presence of Support Factors & & & & \\
\hline 2. Factors of Leaving the Teaching Profession & $.324^{* *}$ & & & \\
\hline 3. Teacher-Student Relations & .024 & -.050 & & \\
\hline 4. Efficacy in Teaching & -.045 & -.141 & $.371^{* *}$ & \\
\hline 5. Professional Burnout & $-.301^{*}$ & .114 & -.148 & -.120 \\
\hline
\end{tabular}

$* \mathrm{p}<.05 . * * \mathrm{p}<.01$ (2-tailed)

Table 2 presents the relationships between the main research indices among teachers who teach in the regular schools. As itcan be seen, support factors were not found to be significantly related to the leaving of the teaching profession. 
In addition, a negative relation was found between the index of the presence of support factors and the index of professional burnout $(\mathrm{r}=-.255, \mathrm{p}=.048)$. Thus, the participants with many significant support factors tended to present lower levels of professional burnout. It was further found that high levels of student-teacher relations are linked positively to higher levels of efficacy in teaching $(r=.550$, $\mathrm{p}=.000)$.

Table 2. Main Research Indices - Teachers from Regular Schools

\begin{tabular}{|l|c|c|c|c|}
\hline & $\mathbf{1}$ & $\mathbf{2}$ & $\mathbf{3}$ & $\mathbf{4}$ \\
\hline 1. Presence of Support Factors & & & & \\
\hline $\begin{array}{l}\text { 2. Factors of Leaving the Teaching } \\
\text { Profession }\end{array}$ & -.096 & & & \\
\hline 3. Teacher-Student Relations & .233 & -.234 & & \\
\hline 4. Efficacy in Teaching & .226 & .080 & $.550^{* *}$ & \\
\hline 5. Professional Burnout & $-.255^{*}$ & -.022 & .125 & -.017 \\
\hline
\end{tabular}

$* \mathrm{p}<.05 . * *^{*}<.01(2$-tailed)

As can be seen in Table 3, the participants' age was found to have a negative relation with the indices of the presence of support factors $(r=-.374, p=.001)$ and efficacy in teaching $(\mathrm{r}=-.232, \mathrm{p}=.049)$. Thus, teachers who are younger tend to have many more support factors and higher teaching efficacy. It was also found that teachers with more years of teaching experience tend to have fewer support factors $(\mathrm{r}=-.277, \mathrm{p}=.018)$ and that teacher with more advanced academic education tend to have better and closer teacher-student relations in comparison to teachers with lower levels of education $(r=.245, \mathrm{p}=.038)$.

Table 3. Demographic Characteristics and Main Research Indices - Teachers from Youth Villages

\begin{tabular}{|l|c|c|c|c|}
\hline & Age & $\begin{array}{c}\text { Number of } \\
\text { Children }\end{array}$ & $\begin{array}{c}\text { Teaching } \\
\text { Experience }\end{array}$ & $\begin{array}{c}\text { Academic } \\
\text { Education }^{1}\end{array}$ \\
\hline Presence of Support Factors & $-.374^{* *}$ & -.098 & $-.277^{*}$ & .050 \\
\hline $\begin{array}{l}\text { Factors of Leaving the Teaching } \\
\text { Profession }\end{array}$ & -.167 & -.037 & $-.216^{\wedge}$ & .057 \\
\hline Teacher-Student Relations & -.212 & $.258^{\wedge}$ & -.025 & $.245^{*}$ \\
\hline Efficacy in Teaching & $-.232^{*}$ & -.195 & -.035 & .139 \\
\hline Professional Burnout & .050 & .036 & -.200 & -.096 \\
\hline
\end{tabular}

${ }^{1}$ Spearman`s rho. ${ }^{*} \mathrm{p}<.05 . * * \mathrm{p}<.01 . \wedge$ almost significant $(\mathrm{p}<.07)$ 
Table 4. Demographic Characteristics and Main Research Indices - Teachers in Regular Schools

\begin{tabular}{|l|c|c|c|c|}
\hline & Age & $\begin{array}{c}\text { Number of } \\
\text { Children }\end{array}$ & $\begin{array}{c}\text { Teaching } \\
\text { Experience }\end{array}$ & $\begin{array}{c}\text { Academic } \\
\text { Education }^{\mathbf{1}}\end{array}$ \\
\hline Presence of Support Factors & -.096 & -.004 & .040 & .016 \\
\hline $\begin{array}{l}\text { Factors of Leaving the Teaching } \\
\text { Profession }\end{array}$ & -.116 & -.231 & $-.292^{*}$ & -.034 \\
\hline Teacher-Student Relations & .144 & $.324^{*}$ & -.098 & 0.28 \\
\hline Efficacy in Teaching & -.126 & .201 & -.142 & -.128 \\
\hline Professional Burnout & .177 & .027 & .044 & .020 \\
\hline
\end{tabular}

${ }^{1}$ Spearman`s rho. ${ }^{*} \mathrm{p}<.05 .{ }^{* *} \mathrm{p}<.01$.

As can be seen in table 5, significant differences were found between the time dedicated by teachers in the regular schools and that of teachers in the youth villages in several areas.

It can be seen that teachers in the youth villages dedicate significantly more time in holding occasional professional conversations with fellow teachers and students $(\mathrm{t}(133)=2.17, \mathrm{p}=.031)$, in holding planned professional meetings with fellow teachers $(\mathrm{t}(136)=2.46, \mathrm{p}=.015)$, and in holding personal conversations with students $(\mathrm{t}(129)=2.57, \mathrm{p}=.011)$. In addition, it can be seen that teachers in the regular schools dedicate significantly more time in the holding of home visits $(\mathrm{t}(130)=-2.25, \mathrm{p}=.017)$.

Table 5. Regular Schools vs. Village Schools in the Time Dedicated a Week (in Hours) to the Need to Perform Tasks of 'Duties and Tasks

\begin{tabular}{|c|c|c|c|c|}
\hline & Gender & $\begin{array}{c}\text { Mean (Stan- } \\
\text { dard Deviation) }\end{array}$ & Test & Significance \\
\hline \multirow[t]{2}{*}{ Preparation of lessons } & Rural & $5.48(3.44)$ & \multirow{2}{*}{$t(136)=1.83$} & \multirow{2}{*}{.069} \\
\hline & Urban & $4.27(4.30)$ & & \\
\hline \multirow[t]{2}{*}{ Teaching in the class } & Rural & $15.58(8.64)$ & \multirow{2}{*}{$t(137)=0.47$} & \multirow{2}{*}{.637} \\
\hline & Urban & $14.58(15.9)$ & & \\
\hline \multirow{2}{*}{$\begin{array}{l}\text { Typing up information regarding } \\
\text { students in the school computer } \\
\text { system }\end{array}$} & Rural & $2.74(1.97)$ & \multirow[b]{2}{*}{$t(133)=1.53$} & \multirow[b]{2}{*}{.126} \\
\hline & Urban & $2.15(2.48)$ & & \\
\hline \multirow{2}{*}{$\begin{array}{l}\text { Evaluation of students' works and } \\
\text { tests }\end{array}$} & Rural & $4.09(2.93)$ & \multirow{2}{*}{$t(132)=0.06$} & \multirow{2}{*}{.951} \\
\hline & Urban & $4.05(5.24)$ & & \\
\hline \multirow{2}{*}{$\begin{array}{l}\text { Professional conversations with } \\
\text { fellow teachers }\end{array}$} & Rural & $3.60(3.33)$ & \multirow{2}{*}{$\mathrm{t}(133)=2.17$} & \multirow{2}{*}{.031} \\
\hline & Urban & $2.41(2.90)$ & & \\
\hline
\end{tabular}




\begin{tabular}{|c|c|c|c|c|}
\hline \multirow{2}{*}{$\begin{array}{l}\text { Planned professional encounters } \\
\text { with fellow teachers (such as staff } \\
\text { meeting) }\end{array}$} & Rural & $3.26(2.39)$ & \multirow{2}{*}{$\mathrm{t}(136)=2.46$} & \multirow{2}{*}{.015} \\
\hline & Urban & $2.23(2.52)$ & & \\
\hline \multirow{2}{*}{$\begin{array}{l}\text { Intervention actions regarding } \\
\text { discipline problems of students }\end{array}$} & Rural & $3.82(5.41)$ & \multirow{2}{*}{$\mathrm{t}(131)=1.84$} & \multirow{2}{*}{.068} \\
\hline & Urban & $2.38(2.95)$ & & \\
\hline \multirow{2}{*}{$\begin{array}{l}\text { Meeting with the counselor/psycho- } \\
\text { logist of the school }\end{array}$} & Rural & $1.34(1.47)$ & \multirow{2}{*}{$\mathrm{t}(131)=1.01$} & \multirow{2}{*}{.313} \\
\hline & Urban & $1.06(1.65)$ & & \\
\hline \multirow{2}{*}{$\begin{array}{l}\text { Filling out official forms regarding } \\
\text { students }\end{array}$} & Rural & $2.11(2.10)$ & \multirow{2}{*}{$t(130)=1.78$} & \multirow{2}{*}{.076} \\
\hline & Urban & $1.43(2.30)$ & & \\
\hline \multirow{2}{*}{$\begin{array}{l}\text { Participation in enrichment } \\
\text { activities of students in the school } \\
\text { framework }\end{array}$} & Rural & $1.70(1.55)$ & \multirow[b]{2}{*}{$\mathrm{t}(128)=0.60$} & \multirow[b]{2}{*}{.550} \\
\hline & Urban & $1.51(2.00)$ & & \\
\hline \multirow{2}{*}{$\begin{array}{l}\text { Participation in professional } \\
\text { training }\end{array}$} & Rural & $2.77(3.22)$ & \multirow{2}{*}{$t(129)=-0.67$} & \multirow{2}{*}{.504} \\
\hline & Urban & $3.48(8.20)$ & & \\
\hline \multirow{2}{*}{$\begin{array}{l}\text { Personal conversations with } \\
\text { students }\end{array}$} & Rural & $3.27(2.97)$ & \multirow{2}{*}{$t(129)=2.57$} & \multirow{2}{*}{.011} \\
\hline & Urban & $2.01(2.52)$ & & \\
\hline \multirow{2}{*}{$\begin{array}{l}\text { Online communication with the } \\
\text { student's parents }\end{array}$} & Rural & $1.73(1.71)$ & \multirow{2}{*}{$t(132)=0.73$} & \multirow{2}{*}{.465} \\
\hline & Urban & $1.50(2.05)$ & & \\
\hline \multirow[t]{2}{*}{ Home visits } & Rural & $0.17(0.47)$ & \multirow{2}{*}{$t(130)=-2.25$} & \multirow{2}{*}{.017} \\
\hline & Urban & $0.49(1.00)$ & & \\
\hline
\end{tabular}

\section{SUMMARY OF THE FINDINGS}

First, it was found among the teachers in youth villages that as the presence of support factors is more significant, the factors that influence the leaving of the profession are more significant. As we can see in Van Droogenbroeck, Spruyt, and Vanroelen ${ }^{20}$, the interpersonal relationships influence the motivation of the teachers. In contrast, this finding does not exist among teachers in regular schools and a significant relationship was not found between the factors for the departure from the profession and the other indices. It could be explained by the unique work in the youth village that is different than regular schools ${ }^{21}$. However, in contrast, both in the regular schools and in the youth villages it was found that participants with many and more significant support sources in the workplace tend to present

${ }^{20}$ Van Droogenbroeck F., Spruyt B., Vanroelen C., Burnout among Senior Teachers: Investigating the Role of Workload and Personal Relationships at Work, "Teaching and Teacher Education" 2014, 43, 99-109.

${ }^{21}$ E. Grupper, The Boarding Schools in Israel: An Original Creation of the Educational System, [in:] Boarding School Education in Israel, ed. S. Shamay, The Educational Center, The Administration for Community Education and Youth Immigration, Tel Aviv 2004 (Hebrew). 
lower levels of professional burnout. It was further found that in both settings, high levels of student-teacher relations are positively linked to higher levels of efficacy in teaching. Furthermore, teachers with higher academic education tend to have better and closer student-teacher relations than teachers with lower levels of academic education. As Fisherman ${ }^{22}$ pointed out, interpersonal relations are one of the causes for teacher burnout.

In addition, it was found that the teachers who teach in the youth villages and who are younger tend to have many more support sources and higher teaching efficacy than do older teachers. It was further found that teachers with greater experience in teaching tend to report the lack of support sources, which means that the age and experience play a role in burnout, for as we see in Gavish and Friedman ${ }^{23}$ the newest teachers in the system tend to leave within the first 5 years.

Examination of the differences in the investment of teachers' time indicates that teachers in the youth villages dedicate more time in holding occasional professional conversation with their fellow teachers, in holding planned professional meetings with fellow teachers, and in holding personal conversations with students. In addition, it was found that teachers in the regular schools dedicate more time in holding home visits. The differences can be explained by the essence of the work in each type of institution, the youth village teachers are substitute for parents as in the regular schools the teachers need to work and learn about the home of the studenet.

In conclusion we can see that there are differences between working in a school and working in a youth village in many aspects. Therefore we can see that the causes for burnout are different, and each type of work emphasizes a different cause. The main understanding is if a youth village teacher in the first year then she has considerable support sources to help her stay in the system.

\section{BIBLIOGRAPHY}

Ariel G., Milstein A., What We Dreamed About: The Legend of the Hadassim, Hisardut 2006 (Hebrew).

Chang M.L., An Appraisal Perspective of Teacher Burnout: Examining the Emotional Work of Teachers, "Educational Psychology Review" 2009, 21, 193-218.

22 S. Fisherman, Professional Identity and Burnout among Teaching Workers, Shanan, Haifa 2016 (Hebrew).

${ }^{23}$ B. Gavish, Y. Friedman, The Teacher as an Organizational Person: The Contribution of the Perceived Work Environment of the Beginning Teacher to the Prediction of Burnout in the Beginning and at the End of the First Year of Work, "Studies in the Administration and Organization of Education" 2007, 29, 55-81 (Hebrew).

${ }^{24}$ E. Grupper, The Boarding Schools in Israel: An Original Creation of the Educational System, [in:] Boarding School Education in Israel, ed. S. Shamay, The Educational Center, The Administration for Community Education and Youth Immigration, Tel Aviv 2004 (Hebrew). 
Dagan D., The Relationship of Coping and Locus of Control to the Adjustment of Immigrant Students from Ethiopia to the Boarding High School, Master Thesis, Bar Ilan University, School of Social Work, Ramat Gan 1997 (Hebrew).

Dvir A., Self-Efficacy and Peer Support, Burnout and Secondary Trauma in a Work Environment Filled with Pressure among Staffs in the Boarding Schools and Children and Youths At Risk. Ph.D. Dissertation, Bar-Ilan University 2007 (Hebrew).

Fisherman S., Professional Identity and Burnout among Teaching Workers, Shanan, Haifa 2016 (Hebrew).

Friedman Y., Lotan A., Mental Burnout of the Teacher in Israel in Elementary Education, Research Report, Henrietta Szold Institute, 1985 (Hebrew).

Friedman Y., Lotan A., Stress and Burnout in Teaching - Causes and Ways of Prevention, Jerusalem: Henrietta Szold Institute1993 (Hebrew).

Gavish B., Friedman I.A., Novice Teachers' Experience of Teaching: A Dynamic Aspect of Burnout, "Social Psychology of Education"2010, 13 (2), 141-167.

Gavish B., Friedman Y., The Teacher as an Organizational Person: The Contribution of the Perceived Work Environment of the Beginning Teacher to the Prediction of Burnout in the Beginning and at the End of the First Year of Work, "Studies in the Administration and Organization of Education" 2007, 29, 55-81 (Hebrew).

Greenfeld A., The Technological Pedagogical Center, The Educational Networks of the Economic Union of Workers in Israel, "The Technological Pedagogical Center, the Amal Network, the Pedagogy Department” 1990 (Hebrew).

Grupper E., To Be an Instructor in the Boarding School: An Ethnographic Investigation of the Process of the Professional Socialization of New Workers to Their Role, Doctoral Dissertation, School of Education, Haifa University, Haifa 1992 (Hebrew).

Grupper E., The Boarding Schools in Israel: An Original Creation of the Educational System, [in:] Boarding School Education in Israel, ed. S. Shamay, The Educational Center, The Administration for Community Education and Youth Immigration, Tel Aviv 2004 (Hebrew).

Grupper E., Boarding Schools in Israel: Social Educational Frameworks and Their Dimensions, [in:] S. Romy, M. Shmeyda (eds.), Informal Education in a Changing Reality, Magnes Press, Jerusalem 2007 (Hebrew).

HaCohen D., Children of Time: Youth Aliyah, 1933-1948, Yad Vashem, The International Ins, Jerusalem 2001.

Keshti Y., Manor A., Boarding Schools in Israel: Continuity and Change, Tel Aviv University, Tel Aviv 1988 (Hebrew).

Levy Z., The Lifestyle in the Boarding School and the Shaping of the Identity of Adolescents, [in:] Communities of Youths, eds. Y. Keshti, S. Shlasky, M. Arieli, Ramot, Tel Aviv 2000 (Hebrew), 21-33.

Pritzker D., Chen D., Factors of Burnout in Teaching among Teachers in Their First Years of Work, "Study and Research in the Training of Teachers" 2010, 12 (Hebrew).

Skaalvik E.M., Skaalvik S., Does School's Context Matters? Relations with Teacher Burnout and Job Satisfaction, "Teaching and Teacher Education” 2009, 25 (3), 518-524.

Struyven K., et al., Why Do They Want to Teach? The Multiple Reasons of Different Groups of Students for Undertaking Teacher Education, "European Journal of Psychology" 2012, 1-16.

Wosner Y., Golan M., Arad-Davidson B., Quality of Life in the Boarding Schools for Children and Youths in Israel: Summative Research Report, Ministry of Labor and Welfare, Jerusalem 1993 (Hebrew).

Van Droogenbroeck F., Spruyt B., Vanroelen C., Burnout among Senior Teachers: Investigating the Role of Workload and Personal Relationships at Work, "Teaching and Teacher Education" 2014, 43, 99-109. 
Author: Vered Azulay

Title: Professional Burnout among Teachers in Regular Schools and Youth Villages in Israel

Keywords: burnout, youth villages, teachers, schools, boarding school

Discipline: Pedagogy

Language: English

Document type: Article

\section{Summary}

The research study addresses the burnout of teachers who teach in regular schools vs. burnout among teachers who teach in youth villages in Israel. The research participants consist of 73 teachers who work with at-risk youths in youth villages in Israel and 70 teachers who work in regular schools, making a total of 143 teachers. A 5-segment self-reporting questionnaire was distributed. The study found a difference in how teachers refer to the factors influencing their departure. In the youth villages, as the factors of support are greater, the factors of departure are more significant. Hence, it is possible to understand that the conclusion that arises from the study is that in order to prevent teacher burnout it is necessary to create many more sources of support, both in regular schools and in youth villages. 